\title{
Variation of constituent loads and concentrations with the flow in Gin river, Sri Lanka
}

\author{
T.N. Wickramaarachchi ${ }^{1^{*}}$, H. Ishidaira ${ }^{2}$ and T.M.N. Wijayaratna ${ }^{1}$ \\ ${ }^{1}$ Department of Civil and Environmental Engineering, Faculty of Engineering, University of Ruhuna, Hapugala, Galle. \\ ${ }^{2}$ Interdisciplinary Graduate School of Medicine and Engineering, University of Yamanashi, Japan.
}

\begin{abstract}
This study was aimed at establishing a detailed understanding on the prevailing constituent loads and concentrations in the Gin river flow at Baddegama, and to reveal how they are related to the river flow. Concentrations and constituent loads in the Gin river at Baddegama (6 $6^{\circ} 11^{\prime} 23^{\prime}$ ' $\mathrm{N}, 80^{\circ} 11^{\prime} 53^{\prime \prime} \mathrm{E}$ ) during 2001 - 2009 were modelled in the study using load-discharge rating curve for estimating constituent loads in rivers. Constituents considered in the study included chloride, total alkalinity, total residue, total hardness, calcium and total iron. For each constituent, the samples tested generally at monthly frequency during 2001 - 2009 at Baddegama were used in conjunction with the observed daily stream flow data to develop and calibrate a multiple regression model.
\end{abstract}

The regression models developed for all constituent loads showed higher coefficients of determination values reflecting a strong relationship between the estimated rating curve and measured constituent loads. The estimated constituent loads had substantial temporal variation and generally peaked in May and October, coinciding with high flows. Load estimates of chloride, total alkalinity, total hardness, and calcium indicated statistically significant downward temporal trends. For the total residue, a statistically significant upward trend was indicated. Concentrations of chloride, total alkalinity, total residue, total hardness, and calcium were well below the highest desirable levels of specifications cited in the Sri Lanka Standards for potable water. However the concentration of total iron, which ranged between $0.8 \mathrm{mg} / \mathrm{L}$ and $4.8 \mathrm{mg} / \mathrm{L}$ significantly exceeded the highest desirable limit for potable water and the maximum permissible limit for inland waters of Sri Lanka.

Keywords: Concentrations, constituent loads, load-discharge rating curve, regression models, stream flow.

\section{INTRODUCTION}

Quantity and quality of water are closely linked. Water quality is the concentration of different constituents in the water including its temperature and state. Water quantity often relates only to discharge and water mass, but the way how water flow varies spatially and temporally is also important. This variation in flow is vital to freshwater ecosystems as discharge and water mass have considerable impacts on physical as well as chemical quality of water (Nilsson \& Renöfält, 2008). In the Sri Lankan context, the major intentional pressures on water resources are agriculture, urbanization and industrialisation that change land use patterns. Excessive use of agrochemicals and chemical fertilizers, release of industrial effluents, domestic waste and sewage, and dumping of solid waste into waterways cause unintentional pressures. These pressures collectively interact resulting in complex impacts on water resources (UNEP, 2001). Several studies have shown the influences of agricultural development, deforestation, and human settlement on river flow and the availability of nutrients in river water (Frenierre, 2009).

The temperature, turbidity and suspended solids in rivers can be greatly affected by human activities such as agriculture, deforestation and the use of water for cooling. The concentration of total suspended solids in rivers increases as a function of flow. Although a general increase can usually be observed in suspended sediment 
concentration with increasing water discharge, it can be affected by a number of river basin processes. Depending on the overall characteristics of the watershed, the peak in suspended sediment may, or may not, occur at the same time as the peak discharge (Chapman, 1996).

Many studies include various methods for load estimation. Estimation of mass loads transported from catchments by rivers fundamentally involves quantifying the total flux of water quality constituents transported by rivers past a point, over a fixed time period (Littlewood, 1992). The common approaches to estimate the total flux involve infrequent estimates of concentrations and frequent estimates of flow. These less than ideal conditions have led to the development of a variety of sampling schemes and computational algorithms to estimate mass loads, including averaging methods, ratio based methods or regression estimators (Yaksich \& Verhoff, 1983; Preston et al., 1989; Burn, 1990; Littlewood, 1992).

The Gin river is one of the main sources of water supply in the Southern region of Sri Lanka. Galle is the capital city in Southern Sri Lanka and the city's pipe-borne water supply system depends on the water resources in Gin river basin. Due to the current development activities in the Southern region owing to substantial land use change, it is believed to be induced some impacts on the quality of water in the Gin river. So far no significant attempt has been made to understand the prevailing concentrations and constituent loads in the Gin river flow. This has been due to various reasons including comparatively high expenses related to sample collection and analysis. As one of the main drinking water supply sources in the Southern region of the country, there exists a vital need to understand the prevailing water quality conditions of Gin river, in order to identify any changes likely to occur in the future subsequent to various anthropogenic activities. This study is an effort to address this need by establishing a detailed understanding on six constituents in Gin river flow at Baddegama, specially focusing how they are related to the river flow.

Load-discharge rating curve (Runkel et al., 2004) for estimating constituent loads in rivers incorporated into the LOADEST, a computer programme developed by the United States Geological Survey (USGS) was used in this study to develop multiple regression models and estimate daily, monthly, and annual loads of the six constituents; chloride, total alkalinity, total residue, total hardness, calcium, and total iron over the period 2001 - 2009. LOADEST is widely used to estimate constituent loads in rivers (Hooper et al., 2001; Aulenbach, 2006; Morrison \& Colombo, 2006; Foster \& Kenney, 2010; Lewis \& Lamoureux, 2010; Stenback et al., 2011) and includes the minimum variance unbiased estimator presented by Cohn et al., (1989), which gives unbiased load estimates. The associated random error in this method is better than the basic rating curve method.

\section{METHODS AND MATERIALS}

\section{Study area}

The Gin river has a catchment area of about $932 \mathrm{~km}^{2}$ and is located approximately between the longitudes $80^{\circ} 08^{\prime \prime} \mathrm{E}$ and $80^{\circ} 40^{\prime \prime} \mathrm{E}$, and latitudes $6^{\circ} 04 " \mathrm{~N}$ and $6^{\circ}$ $30^{\prime \prime} \mathrm{N}$. The Baddegama river gauging station ( $6^{\circ} 11^{\prime} 23^{\prime}$ " $\mathrm{N}, 80^{\circ} 11^{\prime} 53^{\prime \prime}$ E) covers an upstream catchment area of $780 \mathrm{~km}^{2}$. Catchment of the Gin river includes Galle ( $83 \%$ of the basin area), Matara (9\% of the basin area), Rathnapura ( $7 \%$ of the basin area), and Kalutara (1\% of the basin area) administrative districts. The Gin river originates from the Gongala mountains in Deniyaya, which has an elevation of over $1300 \mathrm{~m}$ and flows to the Indian Ocean at Ginthota in Galle District. Rainfall pattern in the catchment is bi-modal, falling between May and September (Southwest Monsoon, which is the major rainfall season), and again between November and February (Northeast Monsoon) followed by the inter-monsoon rains during the remaining months of the year. The rainfall varies with altitude with a mean annual rainfall above $3500 \mathrm{~mm}$ in the upper reaches, to less than $2500 \mathrm{~mm}$ in the lower reaches of the catchment. The Gin river annually discharges about 1268 million cubic meters of water to the sea (Survey Department of Sri Lanka, 2007).

\section{Data}

The water quality data of the Gin river at Baddegama were collected from the National Water Supply and Drainage Board (Southern Province), Sri Lanka. The constituents considered in this study included chloride, total alkalinity, total residue, total hardness, calcium, and total iron. For each constituent, data was obtained from 106 water quality samples tested daily and at monthly frequencies between January 2001 and November 2009. Daily stream flow data at the Baddegama gauging station for the same period was collected from the Department of Irrigation, Sri Lanka. Water quality and stream flow data collected on a given day represented the average concentration and average flow respectively for the day.

\section{Data analysis and model development}

LOADEST, a load-discharge rating curve for estimating constituent loads in rivers was used in this study to 
develop regression models and estimate loads of the six constituents (Runkel et al., 2004). The programme uses time series stream flow data and constituent concentrations to develop and calibrate a regression model that describes constituent loads in terms of various functions of stream flow and time. The calibrated model is then used to estimate constituent loads using daily stream flow observations over a specified time period.

The calibration and estimation procedures within LOADEST are based on three statistical estimation methods; adjusted maximum likelihood estimation (AMLE), maximum likelihood estimation (MLE), and least absolute deviation (LAD). AMLE and MLE methods are appropriate when the calibration model residuals (errors) are normally distributed and AMLE is the method of choice when the calibration dataset contains censored data (constituent concentrations that are less than the laboratory detection limit). LAD is an alternative method to MLE when the residuals are not normally distributed. For the special case where the calibration dataset is uncensored, the AMLE method converges to MLE, resulting in a minimum variance unbiased estimate of constituent loads (Cohn et al., 1992b). Since all the datasets used in this study were uncensored, model coefficients for the AMLE and MLE methods were identical and the AMLE was used to determine the model coefficients and estimate log load for each model. Two statistics, the Akaike information criterion (AIC) and the Schwarz posterior probability criterion, were computed for the calibrated model (Judge et al., 1988; Runkel et al., 2004).

In this study, separate regression models were developed and calibrated for each constituent in estimating the loads. Concentration observations were used in conjunction with corresponding observed stream flow data to develop and calibrate the regression model using AMLE for each constituent. The model with the lowest value of the AIC was then selected for use in load estimation. The regression models developed for each constituent using LOADEST are shown in Table 1.

AMLE results are contingent upon the assumption that model residuals are normally distributed. Once the model formulation and calibration were done, AMLE residuals were examined to see whether the normality assumption was valid. Checks for normality included construction of a normal probability plot, a plot of model residuals versus their Z-scores, which should yield a normal probability plot (Helsel \& Hirsch, 2002; Runkel et al., 2004). The linearity of the plots suggested that the

Table 1: Regression models developed for each constituent using LOADEST and their coefficients of determination $\left(\mathrm{R}^{2}\right)$

\begin{tabular}{|c|c|c|c|c|c|c|c|c|c|}
\hline & \multirow{2}{*}{ Regression model } & \multicolumn{7}{|c|}{ Model coefficients ${ }^{(a)}$} & \multirow{2}{*}{$\mathrm{R}^{2}(\%)$} \\
\hline & & $\mathrm{a} 0$ & a1 & a2 & a3 & $\mathrm{a} 4$ & a5 & a6 & \\
\hline Chloride & $\begin{array}{l}\operatorname{Ln}(\mathrm{L})=\mathrm{a} 0+\mathrm{a} 1 \mathrm{LnQ}+\mathrm{a} 2 \mathrm{LnQ}^{2}+ \\
\mathrm{a} 3 \mathrm{~T}\end{array}$ & $\begin{array}{l}11.38 \\
(0.02)\end{array}$ & $\begin{array}{l}0.96 \\
(0.02)\end{array}$ & $\begin{array}{l}-0.03 \\
(0.02)\end{array}$ & $\begin{array}{l}-0.02 \\
(0.01)\end{array}$ & - & - & - & 97.21 \\
\hline $\begin{array}{l}\text { Total } \\
\text { alkalinity }\end{array}$ & $\operatorname{Ln}(\mathrm{L})=\mathrm{a} 0+\mathrm{a} 1 \mathrm{LnQ}+\mathrm{a} 2 \mathrm{~T}$ & $\begin{array}{l}11.42 \\
(0.03)\end{array}$ & $\begin{array}{l}0.87 \\
(0.04)\end{array}$ & $\begin{array}{l}-0.06 \\
(0.01)\end{array}$ & - & - & - & - & 83.68 \\
\hline $\begin{array}{l}\text { Total } \\
\text { residue }\end{array}$ & $\operatorname{Ln}(\mathrm{L})=\mathrm{a} 0+\mathrm{a} 1 \mathrm{LnQ}+\mathrm{a} 2 \mathrm{~T}$ & $\begin{array}{l}11.51 \\
(0.04)\end{array}$ & $\begin{array}{l}0.82 \\
(0.05)\end{array}$ & $\begin{array}{l}0.03 \\
(0.01)\end{array}$ & - & - & - & - & 74.94 \\
\hline $\begin{array}{l}\text { Total } \\
\text { hardness }\end{array}$ & $\operatorname{Ln}(\mathrm{L})=\mathrm{a} 0+\mathrm{a} 1 \mathrm{LnQ}+\mathrm{a} 2 \mathrm{~T}$ & $\begin{array}{l}11.30 \\
(0.03)\end{array}$ & $\begin{array}{l}0.91 \\
(0.04)\end{array}$ & $\begin{array}{l}-0.04 \\
(0.01)\end{array}$ & - & - & - & - & 82.28 \\
\hline Calcium & $\begin{array}{l}\operatorname{Ln}(\mathrm{L})=\mathrm{a} 0+\mathrm{a} 1 \operatorname{LnQ}+\mathrm{a} 2 \operatorname{Sin}(2 \pi \mathrm{T}) \\
+\mathrm{a} 3 \operatorname{Cos}(2 \pi \mathrm{T})+\mathrm{a} 4 \mathrm{~T}\end{array}$ & $\begin{array}{l}10.78 \\
(0.04)\end{array}$ & $\begin{array}{l}0.93 \\
(0.05)\end{array}$ & $\begin{array}{l}-0.15 \\
(0.06)\end{array}$ & $\begin{array}{l}-0.10 \\
(0.06)\end{array}$ & $\begin{array}{l}-0.07 \\
(0.02)\end{array}$ & - & - & 75.68 \\
\hline $\begin{array}{l}\text { Total } \\
\text { iron }\end{array}$ & $\begin{array}{l}\operatorname{Ln}(\mathrm{L})=\mathrm{a} 0+\mathrm{a} 1 \operatorname{LnQ}+\mathrm{a} 2 \mathrm{LnQ}^{2}+ \\
\mathrm{a} 3 \operatorname{Sin}(2 \pi \mathrm{T})+\mathrm{a} 4 \operatorname{Cos}(2 \pi \mathrm{T})+\mathrm{a} 5 \\
\mathrm{~T}+\mathrm{a} 6 \mathrm{~T}^{2}\end{array}$ & $\begin{array}{l}8.69 \\
(0.08)\end{array}$ & $\begin{array}{l}1.37 \\
(0.06)\end{array}$ & $\begin{array}{l}0.02 \\
(0.06)\end{array}$ & $\begin{array}{l}0.01 \\
(0.07)\end{array}$ & $\begin{array}{l}-0.14 \\
(0.07)\end{array}$ & $\begin{array}{l}-0.03 \\
(0.02)\end{array}$ & $\begin{array}{l}0.02 \\
(0.01)\end{array}$ & 85.72 \\
\hline
\end{tabular}

\footnotetext{
(a) Standard deviation of the model coefficients are shown in parentheses

$\mathrm{L}$ is the constituent load; $\mathrm{Q}$ is the stream flow; $\mathrm{R}^{2}$ is the coefficient of determination for the regression model

Relationships are considered to be significant at $\mathrm{p}<0.05$

$\mathrm{LnQ}=\mathrm{Ln}$ (stream flow) - center of Ln (stream flow); $\mathrm{T}=$ decimal time - center of decimal time

Explanatory variables were centered to eliminate the collinearity (Cohn et al., 1992a; Runkel et al., 2004)
} 
residuals follow a normal distribution. This linearity was supported by the probability plot correlation coefficients of $0.99,0.98,0.94,0.99,0.99$, and 0.96 for chloride, total alkalinity, total residue, total hardness, calcium, and total iron, respectively.

Coefficients of determination $\left(\mathrm{R}^{2}\right)$ of the regression models for constituent loads, which represent fraction of the variance explained by regression are shown in Table 1 . The relatively high $\mathrm{R}^{2}$ values indicated that the models for all constituents successfully simulated the variability in constituent loads.

Constituent concentration data for the model calibration

For each constituent, concentration testings were carried out covering a wide range of flow conditions as shown in the flow duration curve at Baddegama during 2001-2009 (Figure 1). Instantaneous stream flow data and concurrent instantaneous concentration data, which were used for the model calibration are shown in Figure 2a and Figure 2b. Except for total iron, basically no obvious pattern was observed between the stream flow data and the concentration data (Figure 2a). Concentrations of total iron generally followed the pattern of stream flow and tended to be higher when the stream flows were high (Figure 2b).

\section{RESULTS AND DISCUSSION}

\section{Estimation of constituent loads}

In the study, mean load estimates were developed on daily and monthly basis from January 2001 to December 2009 for all the constituents. Mean daily load estimate for each constituent during $2001-2009$ and the errors associated with the load estimates, including upper and lower limits of the $95 \%$ confidence interval are shown in Table 2.

According to Table 2, the ratio of average width of the $95 \%$ confidence interval to mean estimated load of total iron is about $29 \%$ resulting in the least precise load estimates. In contrast, the highest precision is observed for chloride estimation having a ratio of $6.5 \%$.

Measured instantaneous loads were plotted against the estimated loads for the same day to evaluate the fitness of the regression models developed for each constituent (Figure 3). 1: 1 line represents similar values for both estimated and measured. Even distribution of points across the $1: 1$ line for all the constituents indicated that the model neither systematically overestimated nor

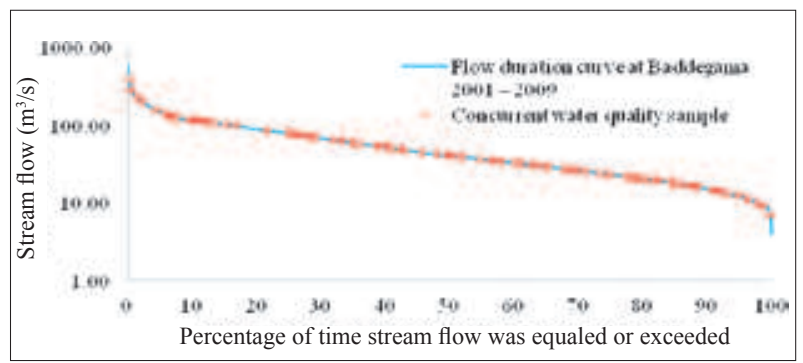

Figure 1: Flow duration curve and concurrent water-quality samples

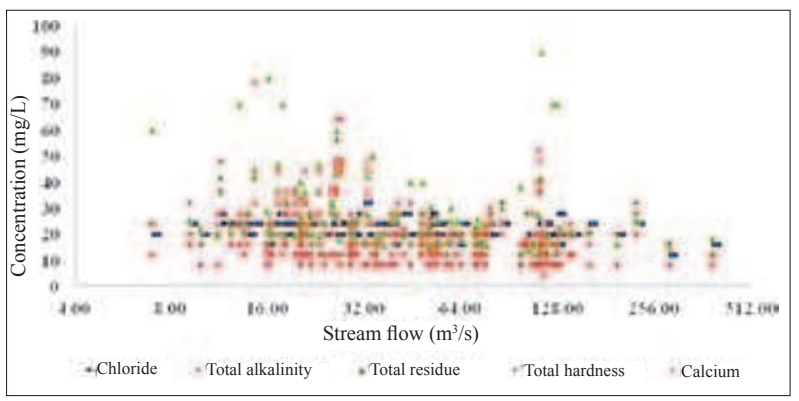

Figure 2a: Constituent concentration and stream flow at Baddegama during $2001-2009$

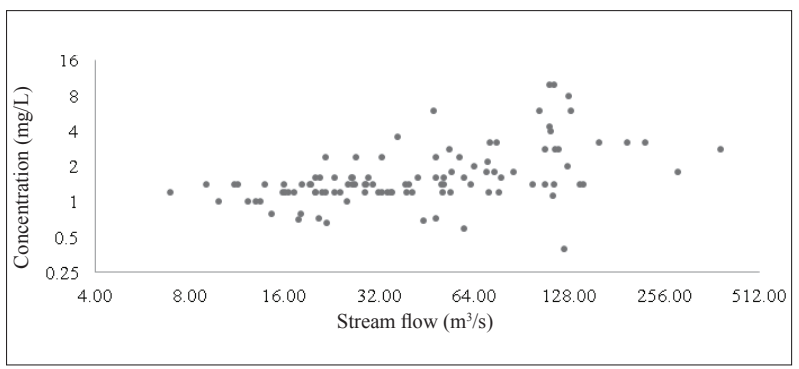

Figure 2b: Total iron concentration and stream flow at Baddegama during 2001 - 2009

underestimated the loads. For chloride and total iron, more points closely clustered near the $1: 1$ line revealed the highest $\mathrm{R}^{2}$ value for the regression model of chloride followed by total iron. The points for total alkalinity and total hardness were moderately scattered and indicated reasonably well distributions near the 1:1 line over a wide range of loads. For total residue and calcium, points were more scattered revealing low $\mathrm{R}^{2}$ values for their regression models. The scatter was very large at higher loads of total residue since the model overestimated large loads. Similarly a large scatter was observed at lower loads of calcium since the model underestimated small loads. But for both total residue and calcium, the models performed reasonably well at moderate loads. 


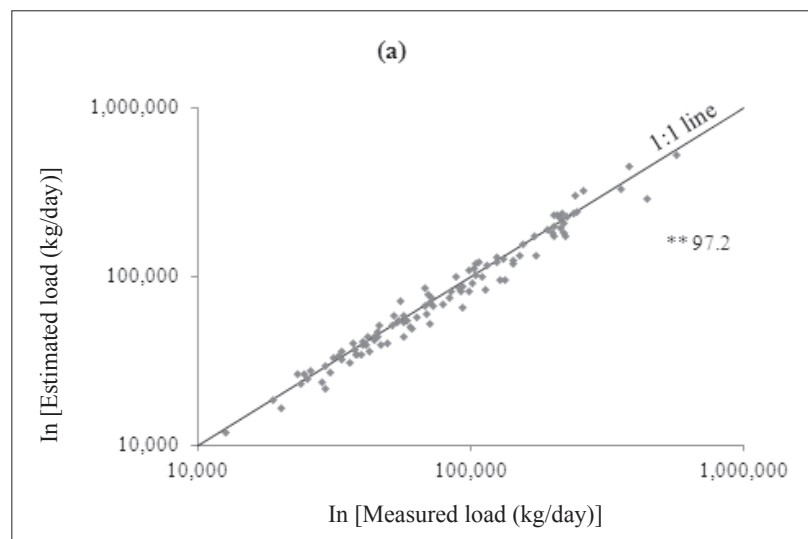

(c)

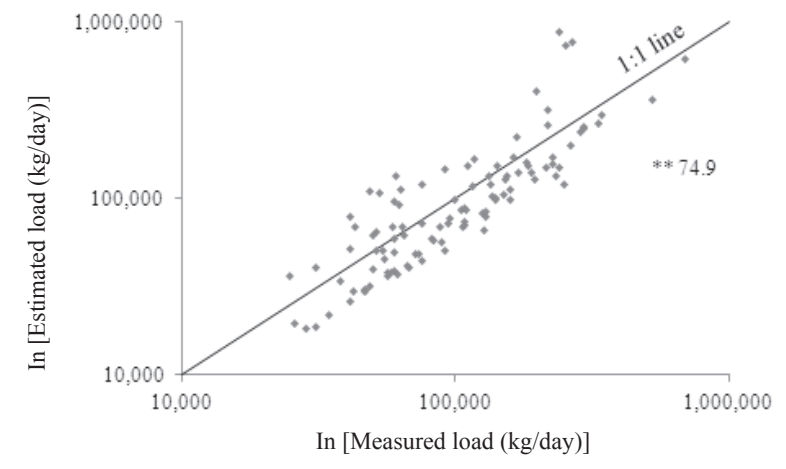

(e)

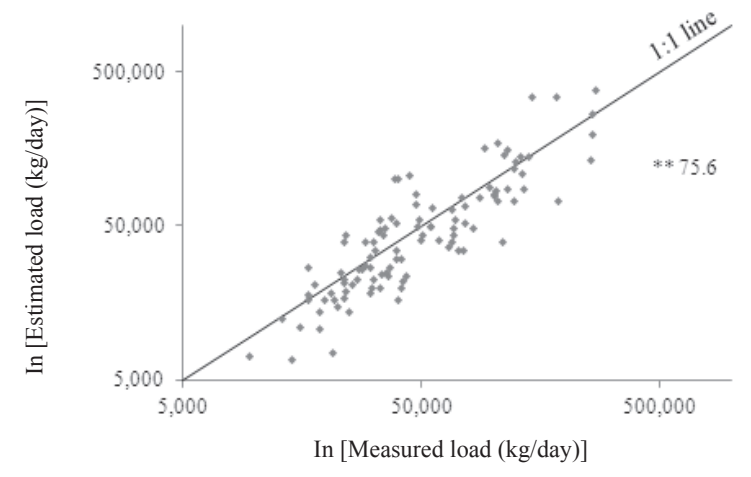

(b)

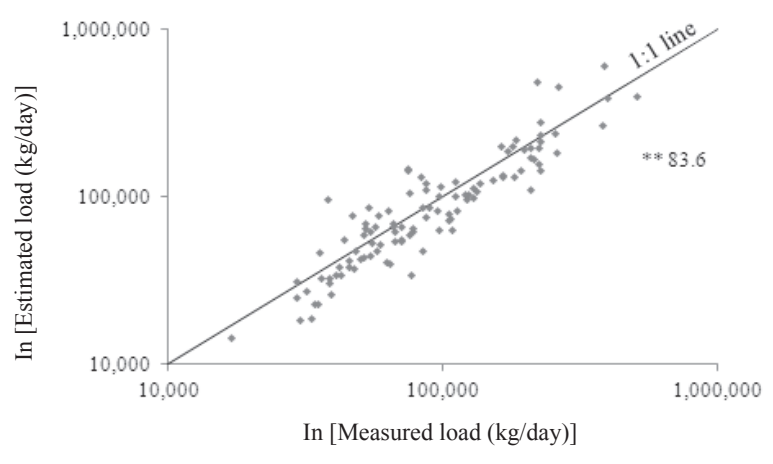

(d)

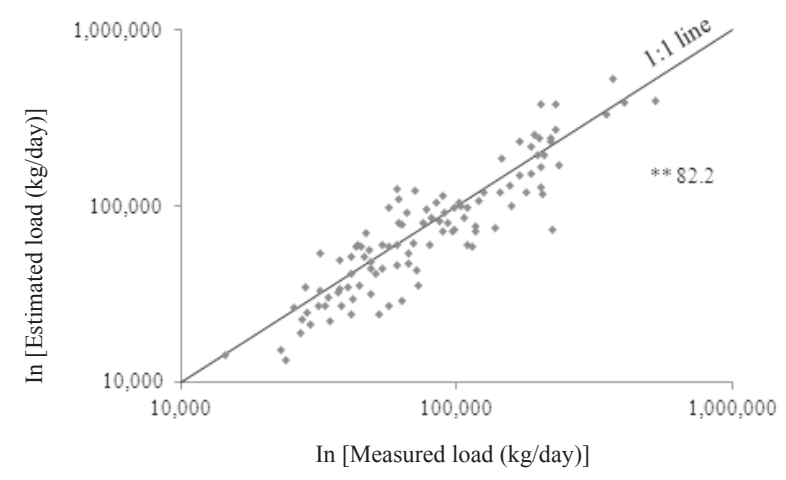

(f)

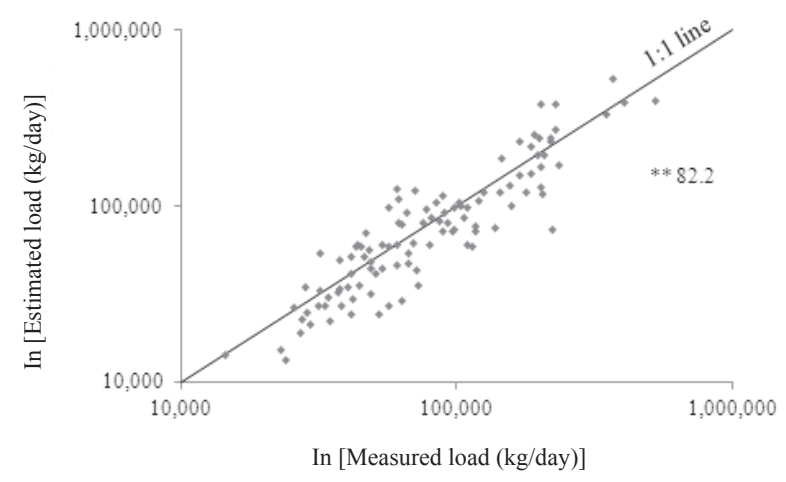

Figure 3: Relationship between measured instantaneous loads and estimated loads (a) chloride; (b) total alkalinity; (c) total residue; (d) total hardness; (e) calcium and (f) total iron

** Coefficient of determination $\left(R^{2}\right)$ for the regression model

Since load is a function of flow (Table 1), a strong relationship determined by high $\mathrm{R}^{2}$ is expected between the load and flow, unless there are very large variations in concentration. Figure 4 compares the measured instantaneous loads and estimated loads with the stream flow during 2001 - 2009 for the regression model where the total residue has the lowest $\mathrm{R}^{2}$. Although the measured and estimated total residue loads 
Table 2: Mean measured loads and mean estimated loads during $2001-2009$

\begin{tabular}{|c|c|c|c|c|c|c|c|}
\hline \multirow[t]{2}{*}{ Constituent } & \multirow[t]{2}{*}{$\begin{array}{c}\text { Mean } \\
\text { measured } \\
\text { load } \\
\text { (tons/day) }\end{array}$} & \multirow[t]{2}{*}{$\begin{array}{c}\text { Mean } \\
\text { estimated load } \\
\text { (tons/day) }\end{array}$} & \multicolumn{2}{|c|}{$\begin{array}{l}\text { Upper and Lower } \\
95 \% \text { confidence } \\
\text { intervals of the mean } \\
\text { estimated load } \\
\text { (tons/day) }\end{array}$} & \multicolumn{2}{|c|}{$\begin{array}{c}\text { Error (as a } \\
\text { percentage of the } \\
\text { mean measured load) }\end{array}$} & \multirow[t]{2}{*}{$\begin{array}{c}\text { Ratio of average } \\
\text { width of the } 95 \% \\
\text { confidence interval } \\
\text { to mean estimated } \\
\text { load (\%) }\end{array}$} \\
\hline & & & Lower & Upper & Lower & Upper & \\
\hline Chloride & 106.32 & 104.16 & 100.81 & 107.58 & $5.18 \%$ & $1.18 \%$ & $6.5 \%$ \\
\hline Total alkalinity & 112.45 & 110.03 & 102.20 & 118.30 & $9.12 \%$ & $5.20 \%$ & $14.6 \%$ \\
\hline Total residue & 132.05 & 125.64 & 113.61 & 138.58 & $13.96 \%$ & $4.95 \%$ & $19.9 \%$ \\
\hline Total hardness & 103.08 & 100.86 & 92.76 & 109.48 & $10.01 \%$ & $6.21 \%$ & $16.8 \%$ \\
\hline Calcium & 63.34 & 61.11 & 54.97 & 67.75 & $13.22 \%$ & $6.96 \%$ & $20.9 \%$ \\
\hline Total iron & 13.23 & 11.55 & 9.98 & 13.31 & $24.60 \%$ & $0.57 \%$ & $28.8 \%$ \\
\hline
\end{tabular}

Table 3: Annual trends in estimated constituent loads during $2001-2009$

\begin{tabular}{lcc}
\hline Constituent load & Annual trend $(\%)$ & $\mathrm{p}$ value \\
\hline Chloride & -0.0217 & $\approx 0$ \\
Total alkalinity & -0.0564 & $\approx 0$ \\
Total residue & 0.0321 & 0.04 \\
Total hardness & -0.0394 & 0.003 \\
Calcium & -0.0715 & $\approx 0$ \\
Total iron & -0.0305 & 0.09 \\
\hline
\end{tabular}

during moderate flows were in reasonable agreement, estimated loads for extreme flow conditions had some deviations from the measured. Total residue loads during the flows greater than $100 \mathrm{~m}^{3} / \mathrm{s}$ were underestimated by the model by about $13 \%$ on average. On the descending limbs of the hydrograph, measured loads were slightly overestimated by the model. As Clark (2003) pointed out, the reason might be that the samples collected during the ascending limb and near the peak of the hydrograph typically contained higher concentrations of sediment than did the samples collected during the descending limb at the same discharge. This is because the material that had accumulated in the stream prior to spring runoff becomes mobile as stream velocities rise, and the concentrations measured later at the same discharge were low because the stream had been flushed of accumulated sediment. However, the model does not account for this and as a result, changes in load resulting from rapid changes in stream flow may not be modelled accurately.

\section{Temporal variations and annual trends in constituent loads}

The mean monthly load estimates and mean monthly stream flow of Gin river at Baddegama during 2001 2009 are shown in Figure 5. The estimated loads were having substantial temporal variation and generally peaked in May and October, coinciding with high flows. Monthly average loads of total residue were consistently higher than the other constituents throughout the year. Annual load estimates of the total residue during 2001 - 2009 ranged from 28,872 to 63,235 tons and indicated the highest annual variation during the estimation period, which was about 4700 tons per year on average.

A trend is present if the loads change consistently as a function of time throughout the estimation period. Statistically significant (95\% confidence level) annual trends for the constituent loads determined in the study are shown in Table 3 and the values are significant at $p<0.05$. For total residue, a statistically significant upward annual trend was indicated. Statistically significant downward annual trends were observed for chloride, total alkalinity, total hardness and calcium. Regression equation for total iron suggested a downward annual trend, but the trend was not statistically significant at the $95 \%$ confidence level.

The reason for the upward trend indicated for total residue could be due to the river sand mining activities in the upstream of the river. The Gin river is one of the major rivers in Southern Sri Lanka suffering most of the illegal and rapid sand mining (Piyadasa et al., 2009). River bed and river bank sand mining activities, which increase erosion could result in raised sediment loads. 


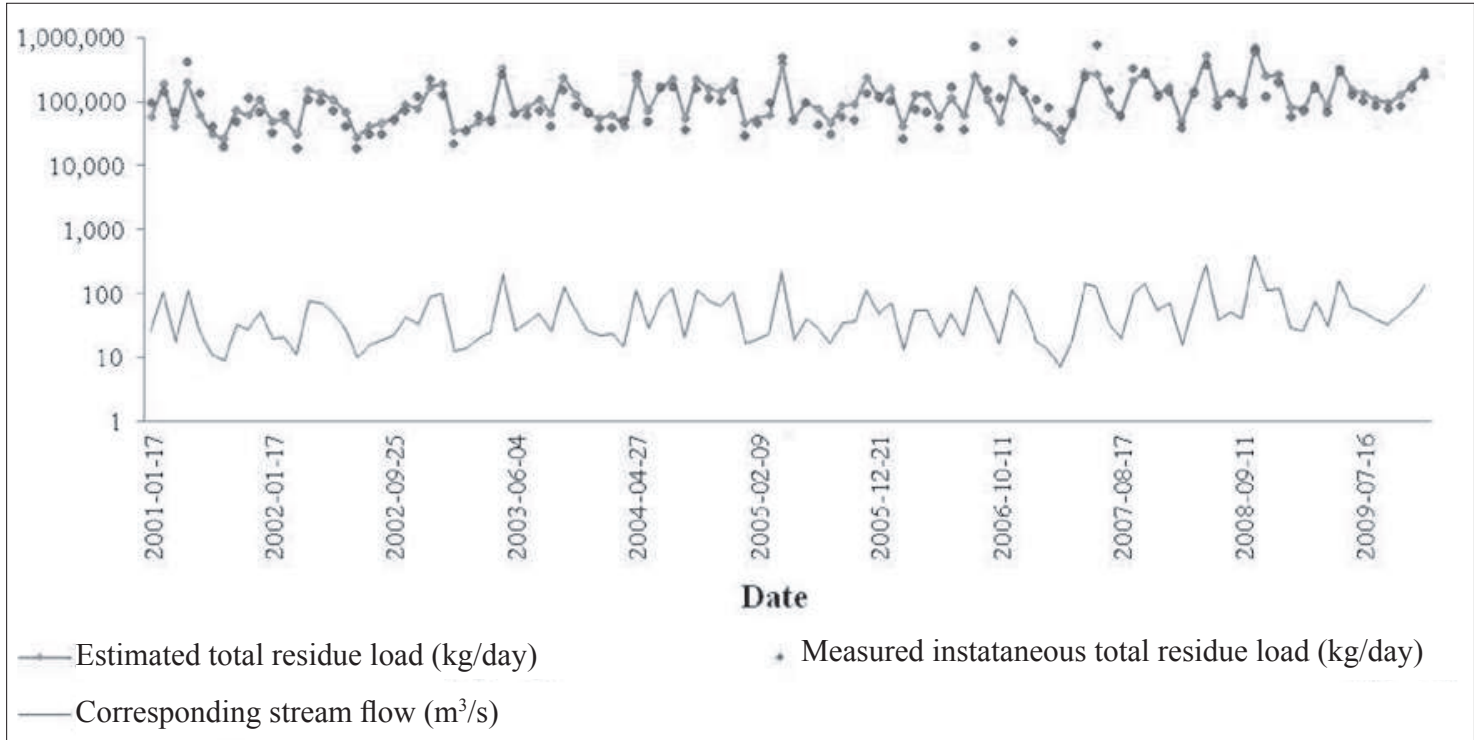

Figure 4: Stream flow, measured instantaneous loads and estimated loads of total residue

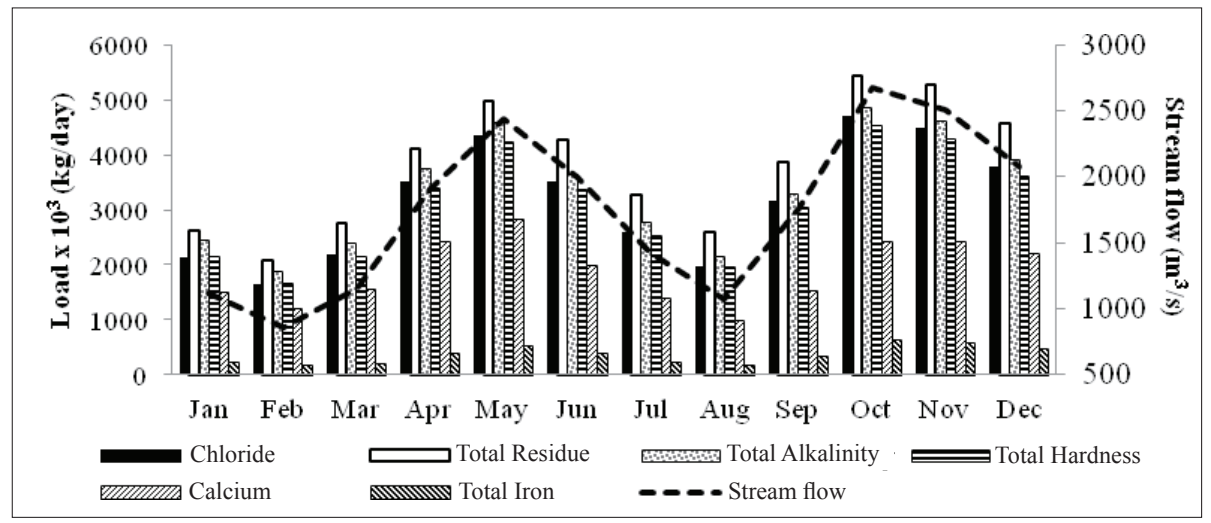

Figure 5: Mean monthly load estimates and mean monthly stream flow of Gin river at Baddegama during $2001-2009$

\section{Constituent comparison with the water quality standards}

Frequency distributions of the constituent concentrations are shown in Table 4. Except for total iron, for all the other constituents, the estimated maximum constituent concentrations were much less than the highest desirable limits of specifications cited in the Sri Lanka Standards for potable water (SLS, 1983) and maximum permissible limits of the proposed ambient water quality standard for inland waters of Sri Lanka by the Central Environmental Authority (CEA, 2001). This is further supported by the chloride and total suspended solid monitoring carried out in the Gin river, recently (Southern Transport
Development Project, 2009). The total iron concentration indicated exceedance of the water quality standards set for potable water as well the inland waters of Sri Lanka (Table 4).

Exceedance of the water quality standards for total iron concentration did occur during all the flow regimes. A plot of total iron concentration vs stream flow exceedance probability showed that higher concentrations were in the range of higher flows (Figure 6). Intensified draining of exposed laterite soils enriched with iron, which are commonly present in the area (Herath, 1983) may be contributing to the higher concentrations of total iron. 
Table 4: Frequency distributions of the constituent concentrations

\begin{tabular}{lcccccc}
\hline \multicolumn{1}{c}{ Constituent } & \multicolumn{2}{c}{ Estimated constituent concentration $(\mathrm{mg} / \mathrm{L})$} & $\begin{array}{c}\text { Sri Lanka } \\
\text { standards } \\
\text { for potable } \\
\text { water a } \\
\text { mg/L }\end{array}$ & $\begin{array}{c}\text { Proposed ambient } \\
\text { water quality } \\
\text { standards for inland } \\
\text { waters of Sri Lanka }{ }^{\mathrm{b}} \\
\mathrm{mg} / \mathrm{L}\end{array}$ \\
\hline Chloride & 15 & 22 & 24 & 25 & 200 & 200 \\
Total alkalinity & 14 & 24 & 32 & 41 & 200 & - \\
Total residue & 17 & 28 & 33 & 41 & 500 & - \\
Total hardness & 15 & 22 & 26 & 31 & 250 & 600 \\
Calcium & 7 & 13 & 19 & 23 & 100 & - \\
Total iron & 0.8 & 1.8 & 2.7 & 4.8 & 0.3 & 1 \\
\hline
\end{tabular}

a Highest desirable level (SLS, 1983)

b Maximum permissible level for CLASS 1 Waters [Drinking water with simple treatment] (CEA, 2001)

- no specific water quality standards available

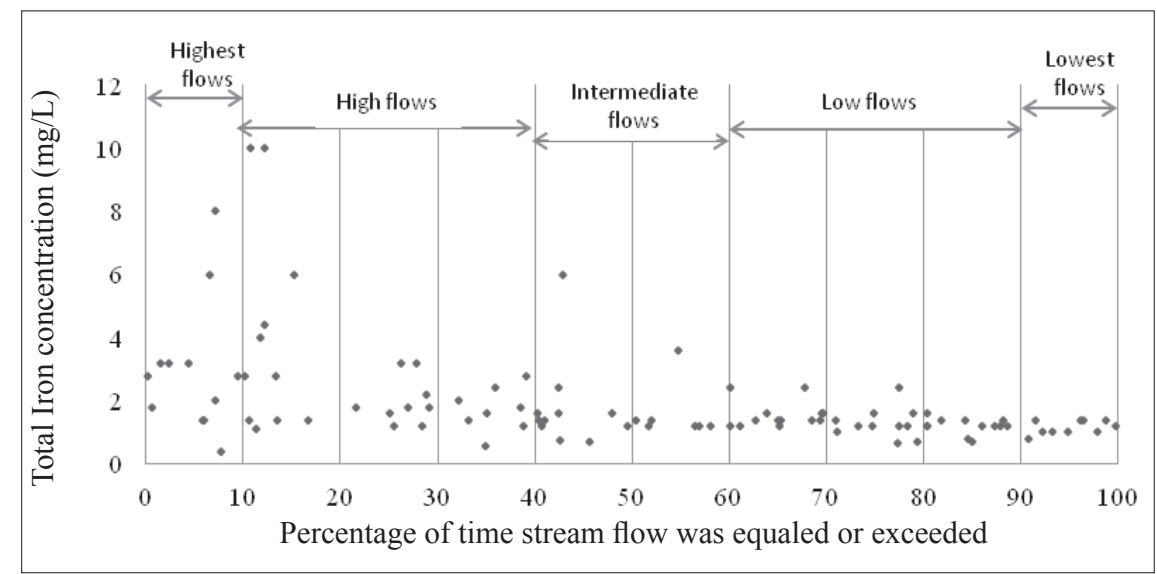

Figure 6: Total iron concentration $v s$ stream flow exceedance probability

The total iron loads were estimated by calculating the $90^{\text {th }}$ percentile of the load within each flow interval. This was done because the $90^{\text {th }}$ percentile of constituent load in a flow interval provides more conservative estimate than the median load, giving an appropriate margin of safety to protect against any underestimation of the median. Percentage reductions necessary to bring the $90^{\text {th }}$ percentile of total iron load estimates down to the water quality criterion $(0.3 \mathrm{mg} / \mathrm{L})$ were calculated (Figure 7).

Figure 7 helps to understand better the fluctuations of the total iron loads during changing flow regimes. Percentage reductions of total iron load necessary to meet the highest desirable level for potable water remain significant under all the flow regimes. Even during the lowest flows, $78 \%$ reduction is required to meet the water quality criterion. Understanding of this excessive amount of iron presented in river water may be useful for water managers and planners to adjust operations accordingly at water treatment plants.

Like in any model, quality of the results given by LOADEST is determined by the quality of input data. Load estimation output data indicated that some of the stream flow values used for estimation exceeded the maximum stream flow values in the calibration dataset. 


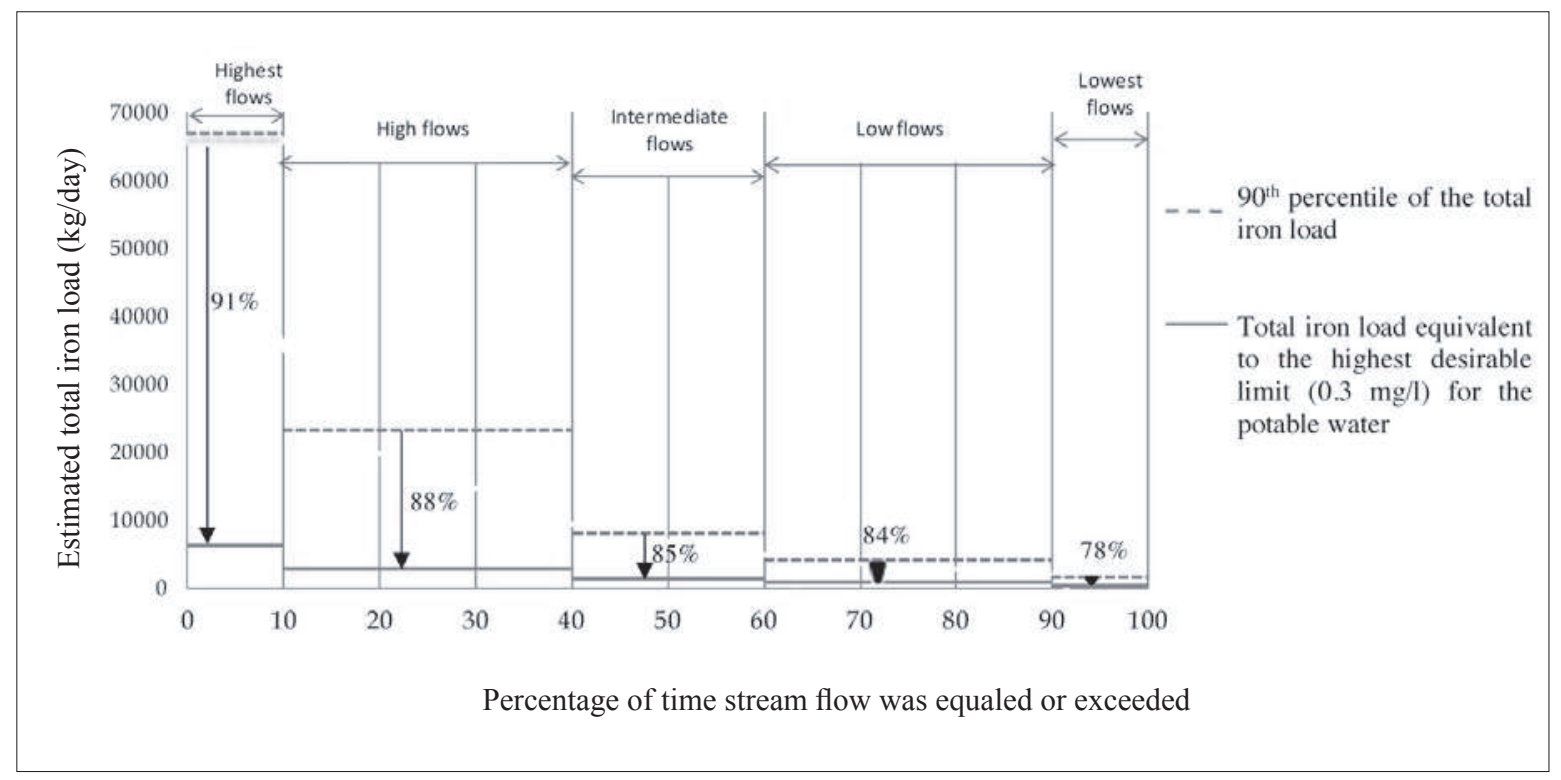

Figure 7: $90^{\text {th }}$ percentile of the total iron load and the percentage reductions of the total iron load necessary to meet the water quality standards

Hence some of the load estimates required extrapolation beyond the range of stream flow used for calibration. Also the quality of the estimate depends on the length of the sampling interval relative to the variation of flow and concentration within the period considered. Although daily discharge measurements are available for the Gin river, constituent concentrations are measured less frequently, such as monthly. According to Littlewood (1992), errors due to inaccuracy and imprecision are quite likely for weekly or longer sampling intervals in estimating suspended sediment loads. Precise and accurate estimates of mass loads could be achieved by regulating sampling effort in line with patterns of mass transport (Degens \& Donohue, 2002). Deliberate and regular sampling, before, during, and after high flows improves LOADEST's ability to estimate loads accurately over a wider range of flow conditions (Donato \& MacCoy, 2005). In this study, the best available data were used through sampling of events representing a sufficiently wide range of flow conditions covering rising limbs, peaks and falling limbs of the flow hydrograph at Baddegama.

The relationships between flow and concentration are rarely straightforward. Both natural and anthropogenic processes, which control how the concentration of a particular constituent varies with flow are many and they interact in an exceedingly complex manner. At a given site, some constituents may exhibit a general decrease in concentration as flow increases; a dilution effect, whilst other constituents exhibit the opposite behaviour; a purging effect (Littlewood, 1992). Since the flow strongly affects the calculation of load, Donato \& MacCoy (2005) recommended the determination of flow-weighted concentrations to facilitate the assessment of changes in concentration over the estimated period, despite a large range in flows. Hence, for the six constituents considered in this study, further analysis on flow-weighted concentrations is recommended to capture the relationship of concentrations to the flow.

\section{CONCLUSION}

LOADEST modelling results included in this study could be used to better understand the fluctuation of concentrations and loads under changing flow regimes and to assess water quality conditions relative to the water quality standards in practice. The prevailing water quality conditions in the Gin river provide baseline information against which evaluation of any changes in water quality that are likely to occur in the future could be made, and would assist water managers and planners to make effective management plans. In addition, due to the overall 'good fit' of the regression models developed for each constituent using the LOADEST, these models could be useful in inferring constituent loads from flow data, during un-sampled periods. 
The future water quality alterations expected in the Gin river and the lack of previous studies on quality of water in the Gin river makes the current assessment of constituent loads and concentrations important. It provides insights into identifying priority areas for analysis and underscores the need for further detailed studies. This study may also be of interest and useful to those who live in the Gin river basin who wish to know more about the quality of water in the area where they live.

\section{Acknowledgement}

The authors gratefully acknowledge the National Water Supply and Drainage Board (Southern Province), Sri Lanka for providing the water quality data of Gin River, Global Centre of Excellence (GCOE) Programme, University of Yamanashi, Japan and the Japan Society for Promotion of Science (JSPS) for providing necessary support for the study including the financial support.

\section{REFERENCES}

1. Aulenbach B.T. (2006). Annual dissolved nitrate plus nitrite and total phosphorus loads for the Susquehanna, St. Lawrence, Mississippi-Atchafalaya and Columbia River basins for 1968 to 2004. Open File Report 2006-1087. US Geological Survey, Reston, USA.

2. Burn D.H. (1990). Real-time sampling strategies for estimating nutrient loadings. Journal of Water Resources Planning and Management 116: 727 - 741.

DOI: http://dx.doi.org/10.1061/(ASCE)0733-9496(1990) 116:6(727)

3. Central Environmental Authority (CEA) (2001). Proposed Ambient Water Quality Standards for Inland Waters of Sri Lanka. Central Environmental Authority, Battaramula.

4. Chapman D. (ed.) (1996). Water Quality AssessmentsA Guide to the Use of Biota, Sediments and Water in Environmental Monitoring. $2^{\text {nd }}$ edition. UNESCO, WHO and UNEP, Chapman and Hall, London, UK.

5. Clark G.M. (2003). Occurrence and transport of cadmium, lead, and zinc in the Spokane River Basin, Idaho and Washington, water years 1999 - 2001. U.S. Geological Survey Water-Resources Investigations Report 02-4183, pp. 37. US Geological Survey, Reston, USA.

6. Cohn T.A., Caulder D.L., Gilroy E.J., Zynjuk L.D. \& Summers R.M. (1992a). The validity of a simple statistical model for estimating fluvial constituent loads - An empirical study involving nutrient loads entering Chesapeake Bay. Water Resources Research 28(9): 2353 $-2363$.

DOI: http://dx.doi.org/10.1029/92WR01008

7. Cohn T.A., Delong L.L., Gilroy E.J., Hirsch R.M. \& Wells D.K. (1989). Estimating constituent loads. Water Resources Research 25(5): 937 - 942. DOI: http://dx.doi.org/10.1029/WR025i005p00937

8. Cohn T.A., Gilroy E.J. \& Baier W.G. (1992b). Estimating fluvial transport of trace constituents using a regression model with data subject to censoring. Proceedings of the Joint Statistical Meeting, Boston, USA, 9 - 13 August, pp. $142-151$.

9. Degens B.P. \& Donohue R.D. (2002). Sampling mass loads in rivers - a review of approaches for identifying, evaluating and minimizing estimation errors, Water Resource Technical Series No WRT 25. Water and Rivers Commission, USA.

10. Donato M.M. \& MacCoy D.E. (2005). Phosphorus and suspended sediment load estimates for the Lower Boise River, Idaho, 1994 - 2002 (version 2.00). U.S. Geological Survey Scientific Investigations Report 2004 - 5235, pp. 30. US Geological Survey, Reston, USA.

11. Foster K. \& Kenney T.A. (2010). Dissolved-solids load in Henrys Fork upstream from the confluence with Antelope Wash, Wyoming, water years 1970 - 2009. U.S. Geological Survey Scientific Investigations Report 2010 - 5048, pp. 16. US Geological Survey, Reston, USA.

12. Frenierre J.L. (2009). The relationship between land change and water resources vulnerability: A review of existing literature. Land Change and Water Resources Vulnerability, Department of Geography, Ohio State University, USA.

13. Helsel D.R. \& Hirsch R.M. (2002). Statistical methods in water resources. U.S. Geological Survey Techniques of Water-Resources Investigations, Book 4, chapter A3. US Geological Survey, Reston, USA.

14. Herath J.W. (1983). Genesis and constitution of Sri Lanka laterites. Journal of National Science Council Sri Lanka 11(2): $277-292$.

15. Hooper R.P., Aulenbach B.T. \& Kelly V.J. (2001). The national stream quality accounting network: a flux-based approach to monitoring the water quality of large rivers. Hydrological Processes 15: 1089 - 1106. DOI: http://dx.doi.org/10.1002/hyp.205

16. Judge G.G., Hill R.C., Griffiths W.E., Lutkepohl H. \& Lee T.C. (1988). Introduction to the Theory and Practice of Econometrics, $2^{\text {nd }}$ edition, pp. 1024. John Wiley, New York, USA.

17. Lewis T. \& Lamoureux S.F. (2010). Twenty-first century discharge and sediment yield predictions in a small high Arctic watershed. Global and Planetary Change 71: $27-41$.

DOI: http://dx.doi.org/10.1016/j.gloplacha.2009.12.006

18. Littlewood I.G. (1992). Estimating contaminant loads in rivers: a review. Report No. 117, Institute of Hydrology, Wallingford, UK.

19. Morrison J. \& Colombo M.J. (2006). Surface-water quality and nutrient loads in the Nepaug Reservoir watershed, northwestern Connecticut, 1999 - 2001. U.S. Geological Survey Scientific Investigations Report 2006-5272, pp. 36. US Geological Survey, Reston, USA.

20. Nilsson C. \& Renöfält B. (2008). Linking flow regime and water quality in rivers: a challenge to adaptive catchment management. Ecology and Society 13(2): 18.

21. Piyadasa R.U.K., Naverathna C.M. \& Athukorela K. (2009). River sand mining and environmental issues in 
Sri Lanka, Joint International Convention of $8^{\text {th }}$ IAHS Scientific Assembly and $37^{\text {th }}$ IAH Congress, Hyderabad, India, 6 - 12 September.

22. Preston S.D., Bierman V.J. \& Silliman S.E. (1989). An evaluation of methods for the estimation of tributary mass loads. Water Resources Research 25: 1379 - 1389.

DOI: http://dx.doi.org/10.1029/WR025i006p01379

23. Runkel R.L., Crawford C.G. \& Cohn T.A. (2004). Load Estimator (LOADEST): A FORTRAN program for estimating constituent loads in streams and rivers. U.S. Geological Survey Techniques and Methods, Book 4, chapter A5, pp. 69. US Geological Survey, Reston, USA.

24. Sri Lanka Standards Institute (SLS) (1983). Sri Lanka Standards for Potable Water - SLS 614. Sri Lanka Standards Institute, Colombo 08.

25. Southern Transport Development Project (2009). Biannual Environmental Impact Monitoring Report. Road
Development Authority, Ministry of Highways and Road Development, Sri Lanka.

26. Stenback G.A., Crumpton W.G., Schilling K.E. \& Helmers M.J. (2011). Rating curve estimation of nutrient loads in Iowa rivers. Journal of Hydrology 396: 158 - 169. DOI: http://dx.doi.org/10.1016/j.jhydrol.2010.11.006

27. Survey Department of Sri Lanka (2007). National Atlas $2^{\text {nd }}$ edition. Survey Department of Sri Lanka, Narahenpita.

28. U.N. Environment Programme (UNEP) (2001). State of the Environment Sri Lanka. United Nations Environment Programme, Regional Resource Centre for Asia and the Pacific (UNEP-RRC.AP).

29. Yaksich S.M. \& Verhoff F.H. (1983). Sampling strategy for river pollutant transport. Journal of Environmental Engineering 109: 219 - 231.

DOI: http://dx.doi.org/10.1061/(ASCE)0733-9372(1983) 109:1(219) 